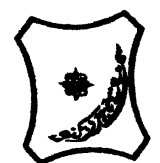

Bayero Journal of Pure and Applied Sciences, 8(1): 132 - 135

Received: January, 2015

Accepted: June, 2015

ISSN $2006-6996$

\title{
EVALUATION OF ANTICONVULSANT PROPERTIES OF ETHANOL STEM BARK EXTRACT OF LOPHIRA LANCEOLATA (OCHNACEAE) IN MICE AND CHICKS
}

\author{
Garba, K. $^{{ }^{*}}$ and Yaro, A.H ${ }^{1}$. \\ ${ }^{1}$ Department of Pharmacology, Bayero University, Kano, Nigeria \\ *Correspondence author: Kgarba.pha@buk.edu.ng, +2348032970383
}

\begin{abstract}
Decoction of Lophira lanceolata known in Hausa as Namijin Kadanya has been used by many communities in northern Nigeria for the treatment of various ailments, commonest of which is epilepsy. The current study is aimed at evaluating the claim of this medicinal plant part by herbalist for the treatment of epilepsy. A preliminary phytochemical screening was performed on the stem bark extract after which intraperitoneal $L D_{50}$ was determined in mice. Anticonvulsant screening was carried out using Maximal electroshock Test (MEST) and pentylenetetrazole (PTZ) in one day old chicks and mice respectively. Flavonoids, saponins, tannins and glycosides were found to be present. The intraperitoneal $L D_{50}$ in mice was found to be $1131.31 \mathrm{mg} / \mathrm{kg}$. There was no significant prolongation in the latency of seizures or protection in both the MEST and PTZ model. Conversely, a significant ( $p \leq 0.05$ ) delay in the mean onset of seizures was recorded with standard drugs, sodium valproate (200 $\mathrm{mg} / \mathrm{kg}$ ) and phenytoin (40 $\mathrm{mg} / \mathrm{kg}$ ) in PTZ and MEST respectively. The findings of this study revealed that the stem bark extract of Lophira lanceolata at the doses tested do not contain any bioactive constituents that is useful in the management of epilepsy.
\end{abstract}

Key words; Epilepsy, maximal electroshock, pentylenetetrazole, Lophira lanceolata

\section{INTRODUCTION}

Epilepsy is defined by International League Against Epilepsy (ILAE) "as a disease of the brain, characterized by two unprovoked reflex seizures occurring 24 hour apart, probability of further seizures occurring over the next ten years and diagnosis of epilepsy syndrome" (Fisher et al., 2014). Epilepsy is a disease that affects about 50 million people across the globe and $85 \%$ of this population resides in developing countries, it is second commonest neurological disorder (Pedley and Kale, 1996; Sridharan, 2002). The prevalence of epilepsy in Nigeria is 3.7-4.1\% (Banerjee et al., 2009). Even with the introduction of safe and efficacious antiepileptic drugs (AED), there is no known cure for epilepsy and relapse is still high, coupled with troubling side effects that leads to discontinuation of therapy (Loscher, 2002). It is therefore, pertinent to widen the scope of search for newer drugs, with potential for treating this neurological disorder; to include plants with ethnomedical documentation for the treatment of epilepsy in our community. The reliance on plants and plant based product for Alternative Medical Practice has been in existence from time immemorial and will continue in the foreseeable future. It is estimated that $11.9 \%$ of patients visiting epileptic clinics in Kano are on one form of native treatment or the other (Owolabi and Sale, 2011).

Medicinal plants are important recipe of Traditional Medical Practice. It is estimated that 8 out of 10 people in the developing world depend on medicinal plants for their primary health care needs (Fransworth et al., 1985). Several drug molecules such as morphine, strychnine, atropine, vincristine among others were isolated and developed from medicinal plants (Newman and Cragg, 2012). Lophira lanceolata (Ochnaceae) known as 'Namijin Kadanya' by the Hausas is used by many communities in the treatment of epilepsy in northern Nigeria, Similarly, it is used extensively in northern Nigeria for erectile dysfunction (Etuk et al., 2009). Previous studies on the leaves of the plants revealed antiplasmodial activity (Collins et al., 2014). Lophira lanceolata is a tree that grows up to $12 \mathrm{~m}$ high, with a narrow crown, deep root, less scaly bark and contains no latex. It is abundant in moister bush savannah regions, from Senegal, Nigeria, Sudan, and Uganda, and across Sub Saharan region. It is resistant to fire damage and consequently used to protect the soil (Burkill, 1985; Arbonnier, 2004)

Even though, this plant has been used for ages for the treatment of epilepsy, to the best of our knowledge, no scientific evaluation of this claim has been reported. The aim of the present study is to screen the stem bark extract of the plant for anticonvulsant effect using standard anticonvulsant screening.

\section{MATERIALS AND METHODS}

Source of plant material

The stem bark of the plant was collected around June, 2013 in Zaria, Nigeria. It was identified by a Taxonomist in the Herbarium section, Department of Biological Sciences, Ahmadu Bello University, Zaria, by comparing with already deposited voucher specimen number 7198. 


\section{Preparation of the plant material}

The stem bark was cleaned, cut into smaller size and air dried at room temperature. The material was then milled into powder using pestle and mortar. Extraction was carried out by cold maceration where $1.1 \mathrm{~kg}$ of the powder was dissolved in $4.2 \mathrm{~L}$ of $70 \% \mathrm{v} / \mathrm{v}$ ethanol for 3 days with occasional shaking using glass stirrer. The resultant mixture was filtered using Whatman filter paper (No. 1) and the filtrate was concentrated to dryness in vacuo at $40^{\circ} \mathrm{C}$ using rotary evaporator.

Animals

Swiss albino mice (18-32g) of either sex were obtained from the Animal Facility Centre (AFC) Department of Pharmacology, Bayero, University, Kano, Nigeria, while day old cockerels were obtained from National Animal Production Institute of Nigeria (NAPRI), Zaria, Nigeria. Animals were maintained in a well ventilated room and fed with standard feeds and water provided ad libitum. We certify that all experiments were carried out in accordance with the National Institute of Health Guidelines for the Care and Use of Laboratory Animals $\{\mathrm{NIH}$ Publications No.80-23\} revised in 1996. All efforts were made to minimize the number of mice and chicks used and their suffering.

\section{Phytochemical screening}

The phytochemical screening was performed on the dried stem bark extract of Lophira lanceolata using standard procedure (Trease and Evans, 1997).

\section{Acute toxicity testing}

The intraperitoneal $\mathrm{LD}_{50}$ was determined in mice. The study was carried out in two phases. In the first phase, nine mice of either sex were randomly divided into three groups of three mice each and were administered 10,100 and $1,000 \mathrm{mg} / \mathrm{kg}$ of the extract intraperitonially. Mice were observed for signs and symptoms of toxicity including death over a period of 24 hours. In the second phase of the study, $200,400,800$ and $1600 \mathrm{mg} / \mathrm{kg}$ body weight of the extracts were given to four different groups of one mouse each intraperitonially (i.p.) based on the result of the first phase. The $\mathrm{LD}_{50}$ was estimated by calculating the geometric mean of the lowest dose that caused death (1/1) and the highest dose that animal survived (0/1) (Lorke, 1983).

\section{Pentylenetetrazole induced seizures in mice}

Animals were divided into five groups of six mice each. Group 1 received normal saline $(10 \mathrm{ml} / \mathrm{kg})$, group 2,3 and 4 received the extract at the doses of 85,170 and $340 \mathrm{mg} / \mathrm{kg}$ of body weight respectively, while group 5 received standard drug sodium valproate at a dose of $200 \mathrm{mg} / \mathrm{kg}$ intraperitonially. Thirty minutes later, mice in the groups received $100 \mathrm{mg} / \mathrm{kg}$ PTZ subcutaneously $\left(C D_{100}\right)$. Animals were observed for the presence or absence of threshold seizures (an episode of clonic spasm of at least 5 second duration), mean onset of convulsion, quantal protection and percent protection, number of convulsions and time to death according to the method of (Swinyard et al. 1989).

\section{Maximal Electro Shock Test in chicks}

The apparatus used was Ugo Basile Electroconvulsive Machine (Model 7801) with corneal electrodes placed on the upper eyelid of the chicks after dipping them in normal saline. The current, shock duration, pulse width and frequency were set and maintained at $80 \mathrm{~mA}, 0.6 \mathrm{sec}, 0.6 \mathrm{~ms}$ and 100 pulses per second respectively. Fifty day old cockerels were grouped into five groups of ten chicks each. Group 1 was pretreated with normal saline $(10 \mathrm{ml} / \mathrm{kg}$ i.p.), group 2, 3 and 4 were administered with extract at doses of $85,170,340 \mathrm{mg} / \mathrm{kg}$ body weight intraperitonielly, while group 5 was treated with phenytoin sodium $20 \mathrm{mg} / \mathrm{kg}$ body weight intraperitonielly. Thirty minutes post treatment, electroshock was administered to each animal to induce convulsion. Results were recorded as either positive or negative depending on whether tonic hind limb extension (THLE) was produced. The time of recovery of convulsed chicks were recorded and the percentage of convulsed animals calculated (Swinyard and Kupferberg, 1985).

\section{Strychnine-induced seizures in mice}

Mice were grouped into 5 groups of 6 mice each. Group 1 received $10 \mathrm{ml} / \mathrm{kg}$ of normal saline, group 2, 3 and 4 were administered with the extract at doses of 85,170 and $340 \mathrm{mg} / \mathrm{kg}$ body weight respectively while group 5 received phenobarbitone at a dose of $30 \mathrm{mg} / \mathrm{kg}$ body weight intraperitonielly. Thirty minutes later, mice were administered 1.2 $\mathrm{mg} / \mathrm{kg}$ body weight of strychnine subcutaneously and observed for incidence of convulsions. Prevention of tonic hind limb extensor jerk was considered as protection against seizures induced by strychnine (Lehmann et al., 1988).

\section{Picrotoxin induced seizures in mice}

Thirty mice were grouped into five each consisting of six mice. The mice in first group received normal saline $(10 \mathrm{ml} / \mathrm{kg})$, the second, third and fourth groups were injected with the extract at doses of 85,170 and $340 \mathrm{mg} / \mathrm{kg}$ body weight respectively. The fifth group received phenobarbitone $30 \mathrm{mg} / \mathrm{kg}$ body weight, all via intraperitoneal route. Thirty minutes later, mice in all the groups were given picrotoxin subcutaneously $5 \mathrm{mg} / \mathrm{kg}$. They were then observed for hind limb tonic extension over 30 minutes period. Absence of tonic hind limb extension or prolongation of the latency of the hind limb tonic extension was considered as an indication for anticonvulsant activity (Salih and Mustafa, 2008).

\section{Statistical analysis}

Results were expressed as Mean \pm Standard Error of Mean (SEM). Statistical analysis was done by Analysis of Variance (ANOVA), a Dunnett's post hoc test was done, when statistically significant result was obtained with ANOVA. Values of $p \leq 0.05$ were considered significant. SPSS version 20 was used for the analysis.

\section{RESULTS}

\section{Phytochemical studies}

Preliminary phytochemical screening of the stem bark extract of Lophira lanceolata revealed the presence of flavonoids, tannins, saponins and glycosides (Table 1). 


\section{Acute toxicity test}

The intraperitoneal $L_{50}$ was calculated to be 1131.31 $\mathrm{mg} / \mathrm{kg}$ in mice. Decreased in physical activity was noted in the mice before death.

\section{Anticonvulsant studies}

The ethanol extract of Lophira lanceolata at all doses tested $(85,170$ and $340 \mathrm{mg} / \mathrm{kg}$ ) do not have any effect on mean onset of convulsion, mean number of clonic spasm and time to death. However, sodium valproate $(200 \mathrm{mg} / \mathrm{kg})$ significantly $(P \leq 0.05)$ delayed the mean onset of convulsion induced by PTZ when compared with normal saline treated group (Table 2).

The ethanol stem bark extract of Lophira lanceolata had no effect on the mean recovery time of convulsed animals after maximal electroshock at all the tested doses $(85,170$ and $340 \mathrm{mg} / \mathrm{kg}$ ) when compared with normal saline treated group. Conversely, phenytoin a standard drug at a dose of $40 \mathrm{mg} / \mathrm{kg}$ significantly $(\mathrm{p} \leq 0.05)$ protected all the animals from tonic hind limb extension induced by MEST (Table 3).

\section{TABLE 1: Phytotochemical constituents of ethanol stem bark extracts of Lophira lanceolata}

\begin{tabular}{|c|c|c|c|c|c|c|}
\hline \multicolumn{2}{|c|}{ Constituents } & Inference & & & & \\
\hline \multicolumn{7}{|l|}{ Flavonoids } \\
\hline \multicolumn{2}{|c|}{ a. Sulphuric acid test } & - & & & & \\
\hline \multicolumn{2}{|c|}{ b. Lead acetate test } & + & & & & \\
\hline \multicolumn{2}{|c|}{ c. Shinoda test } & + & & & & \\
\hline \multicolumn{7}{|c|}{ Tannins } \\
\hline \multicolumn{2}{|c|}{ a. General test } & + & & & & \\
\hline \multicolumn{2}{|c|}{ b. Ferric chloride test } & + & & & & \\
\hline \multicolumn{2}{|c|}{ c. Phlobatannins } & + & & & & \\
\hline \multicolumn{7}{|c|}{ Saponins } \\
\hline \multicolumn{2}{|c|}{$\begin{array}{l}\text { a. Frothing test } \\
\text { Alkaloids }\end{array}$} & + & & & & \\
\hline \multicolumn{2}{|c|}{ a. Dragendorff's test } & - & & & & \\
\hline \multicolumn{2}{|c|}{ b. Mayer's test } & - & & & & \\
\hline \multicolumn{2}{|c|}{ c. Wagner's test } & - & & & & \\
\hline \multicolumn{7}{|c|}{ Glycosides } \\
\hline \multicolumn{2}{|c|}{$\begin{array}{l}\text { a. Salkowski's test } \\
\text { b. Keller-Kelliani's test }\end{array}$} & + & & & & \\
\hline \multicolumn{7}{|c|}{ Steroids/terpenoids } \\
\hline \multicolumn{2}{|c|}{$\begin{array}{l}\text { a. Lieberman Burchard } \\
\text { test }\end{array}$} & $d$ & & & & \\
\hline \multicolumn{2}{|c|}{ Anthraquinones } & - & & & & \\
\hline \multicolumn{7}{|c|}{ Key: + present, - absent } \\
\hline Treatment & $\begin{array}{l}\text { Dose } \\
(\mathrm{mg} / \mathbf{k g})\end{array}$ & $\begin{array}{l}\text { Mean onset } \\
\text { seizures (min) }\end{array}$ & & $\begin{array}{l}\text { Mean No. } \\
\text { clonic spasm }\end{array}$ & $\begin{array}{l}\text { of Quantal } \\
\text { protection }\end{array}$ & $\begin{array}{l}\text { Time to Death } \\
\text { (Min) }\end{array}$ \\
\hline N/Saline & $10 \mathrm{ml} / \mathrm{kg}$ & $5.00 \pm 0.73$ & & $2.83 \pm 0.40$ & $0 / 6$ & $10.60 \pm 2.66$ \\
\hline $\begin{array}{l}\text { Sodium } \\
\text { Valproate }\end{array}$ & 200 & $11.50 \pm 1.43^{*}$ & & $1.16 \pm 0.16$ & $0 / 6$ & $14.00 \pm 3.79$ \\
\hline LL 85 & 85 & $7.67 \pm 1.73$ & & $2.16 \pm 0.53$ & $0 / 6$ & $8.67 \pm 1.33$ \\
\hline LL 170 & 170 & $8.17 \pm 1.83$ & & $1.50 \pm 0.54$ & $0 / 6$ & $9.17 \pm 1.42$ \\
\hline LL340 & 340 & $6.33 \pm 1.48$ & & $1.16 \pm 0.40$ & $0 / 6$ & $8.25 \pm 0.85$ \\
\hline
\end{tabular}

Data presented as Mean \pm SEM, $\mathrm{n}=6$, $\mathrm{LL}=$ Lophira lanceolata, $* \mathrm{P} \leq 0.05$, one way ANOVA.

Table 3: Effect of ethanol stem bark of Lophira lanceolata on MEST induced seizures in chicks

\begin{tabular}{lllll}
\hline Treatment & Dose & $\begin{array}{l}\text { Mean recovery } \\
\text { time (Min) }\end{array}$ & $\begin{array}{c}\text { Quantal } \\
\text { protection }\end{array}$ & \% Protection \\
\hline Normal Saline & $10 \mathrm{ml} / \mathrm{kg}$ & $5.44 \pm 0.89$ & $1 / 10$ & 10.00 \\
Phenytoin & 40 & - & $10 / 10$ & 100 \\
LL 85 & 85 & $7.60 \pm 1.21$ & $0 / 10$ & 0.00 \\
LL 170 & 170 & $6.10 \pm 0.56$ & $0 / 10$ & 0.00 \\
LL 340 & 340 & $8.60 \pm 1.62$ & $0 / 10$ & 0.00 \\
\hline
\end{tabular}

Data presented as Mean $\pm \mathrm{SEM}, \mathrm{n}=10, \mathrm{LL}=$ Lophira lanceolata, one way ANOVA, - = no convulsion

\section{DISCUSSION}

The intraperitoneal $L D_{50}$ value of the stem bark extracts of Lophira lanceolata was calculated to be 1131.13 $\mathrm{mg} / \mathrm{kg}$ which suggested that the extract is relatively safe (Lorke, 1983). Furthermore, the doses employed in this studies, is less than one third of the $\mathrm{LD}_{50}$ value which is adjudged to be safe for pharmacological experiments. The extracts neither offer any protection against picrotoxin induced seizures nor prolong the latency of convulsion. This clearly, demonstrated that it is 
ineffective against seizures induced by picrotoxin. Drugs that are effective in abolishing or suppressing seizures by picrotoxin in rodents are beneficial in absence seizures; they do so by raising the seizure threshold. Example of such agents includes sodium valproate, ethosuximide and benzodiazepines. It is thought that picrotoxin antagonized the central action of Gamma amino butyric acid (GABA) and central noradrenergic neurons (Corda et al., 1990). Similarly, the extracts did not provide any effect against seizures induced by Maximal electroshock (MEST). The MEST model identifies drugs that are active against generalized tonic clonic seizures. Agents that are active against the Tonic Hind Limb Extension (THLE) induced by MEST act by limiting the spread of seizures (Porter and Meldrum, 2012). The inability of the extract to decrease the mean recovery time of convulsed animals and protect the

\section{REFERENCES}

Arbonnier, M. (2004). Trees, Shrubs and Lianas of West African dry Zones 2nd ed. M. Arbonnier, ed., Netherlands: Cirad,Margraf Publishers GMBH. 348.

Audu, S., Mohammed, I. and Kaita, H. (2007). Phytochemical screening of the leaves of Lophira lanceolata (Ochanaceae). Life Science Journal, 4(4):75-79.

Banerjee, P.N., Filippi, D. and Allen Hauser, W. (2009). The descriptive epidemiology of epilepsy-a review. Epilepsy research, 85(1): 31-45.

Burkill, H.M. (1985). The Useful Plants of West Tropical Africa 2nd ed. H. M. Burkill, ed., Kew: Royal Botanic Gardens. 4, 271-272.

Collins, A.O., Peter, A.A., Chukwuemeka, S.N., Theophine, C.O.,Florence, N.M., Ifeoma, A.N., Nelson,O. and Obinna, O. (2014). Antiplasmodial and antioxidant activities of methanol extract of the fresh leaf of Lophira lanceolata (Ochnaceae). African Journal of Biotechnology, 13(16): 1731-1738.

Corda, M.G., Giogio, O., Longoni, B., Orlandi, M., and Biggio, G. (1990). Decrease in the function of gamma amino butyric acid-coupled chloride channel produced by the repeated administration of pentylenetetrazole in rats. Journal of Neurochemistry, 55(4): 1216-1221.

Etuk, E.U., Muhammad, A.A.,Igbokwe, V. and Okolo. R.O. (2009). Sexual stimulatory effects of aqueous stem bark extract of Lophira laceolata in male Sprague Dawley rats. , 1(2):18-21.

Faggion, S.A., Cunha, A.S., Fachim, H.A., Gavin, A.S., dos Santos,W.F., Pereira,AM.S. and Beleboni, R.O. (2011). Anticonvulsant profile of the alkaloids (+)-erythravine and (+)-11-a-hydroxyerythravine isolated from the flowers of Erythrina mulungu Mart ex Benth (Leguminosae-Papilionaceae). Epilepsy and behavior: 20(3): 441-6.

Fisher, R.S., Acevedo, C., Arzimanoglou, A., Bogacz, A., Cross, J.H., Elger, C.E., Engel, J., Forsgren, L., French, J.A., Glynn, M., Hesdorffer, D.C., Lee, B.I., Mathern, G.W., Moshe, S.C., Perucca, E., Scheffer, I.E., Tomson, T., Watanabe, M. and Wiebe, S. (2014). ILAE official report: a chicks against THLE induced by MEST suggested that extract is not useful in the management of generalized tonic clonic seizures. The preliminary phytochemical screening found the presence of flavonoids, tannins, saponins and glycosides. This finding corroborated earlier work on the same plant part where similar secondary metabolites were reported (Audu et al., 2007). Alkaloids have been reported to posses' anticonvulsant activity (Faggion et al., 2011), which were not detected in this extract. Thus, absence of this secondary metabolite might be responsible for the lack of anticonvulsant effect observed in this extract.

\section{CONCLUSION}

Based on the data presented, it can be inferred that the use of stem bark of Lophira lanceolata for the management of epilepsy in folk medicine is not scientifically justifiable.

practical clinical definition of epilepsy. Epilepsia, 55(4): 475-82

Fransworth, N.R. (1985). Bull. WHO, 63:965.

Lehmann, J., Hutchison, A., McPherson, S. , Mondadori, C., Schmutz, M., Sinton, C., Wood, P., (1988). Cas 19755, a selective and competitive Nmethyl-D-aspartate-type excitatory amino acid receptor antagonist. Journal of Pharmacology and Experimental Therapeutics, 246, 65-75.

Lorke, D.( 1983). A New Approach to Practical Acute Toxicity Testing. Archives of Toxicology, 54: 275-287.

Loscher, W. (2002). Current status and future directions in the pharmacotherapy of epilepsy. Trends Pharmacological Sciences, 23: 113-118.

Newman, D.J. and Cragg, G.M. (2012). Natural products as sources of new drugs over the 30 years from 1981 to 2010. Journal of natural products, 75(3): 311-35.

Owolabi, L.F. and Sale, S. (2011). Clinical profile of patients with epilepsy in developing countries: experience at kano. Borno Medical Journal, 8(2): $1-14$.

Pedley, T. and Kale, R. (1996). Epilepsy information for the developing world. Epilepsia Digest, 1(1). 455-457.

Porter, R.J. and Meldrum, B.S., (2012). Antiseizure Drugs. In K. G. Katzung, S. B. Masters, \& A. J. Trevor, eds. Basic clinical pharmacology. New York, 1403-425.

Salih, M.A. and Mustafa, M.M., (2008). A substance in broad beans (Vicia faba) is protective against experimentally induced convulsions in mice. Epilepsy \& behavior: E\&B, 12: 25-29.

Sridharan, R., (2002). Epidemiology of epilepsy. Current science, 82(6): 664-670.

Swinyard, E.. A., Woodhead,J.H., White, H.S. and Franklin, M.R. (1989). General principles: experimental selection, quantification and evaluation of anticonvulsants. In R. H. Levy et al., eds. Antiepileptic Drugs. New York: Raven Press, 154-163.

Swinyard, E.A. and Kupferberg, H.J. (1985). Antiepileptic drugs: detection, quantification, and evaluation. Federation proceedings, 44(10): 2629-33.

Trease, G.E. and Evans, W. (1997). Pharmacognosy Textbook 4th ed. G. E. Trease \& W. C. Evans, eds., India: Harcourt Brace. 269-275. 